\title{
Process and Product: Creating Stories with Deaf Students
}

\author{
Charlotte Enns, Ricki Hall, \\ Becky Isaac, and Patricia MacDonald
}

This article describes the implementation of one element of an adapted language arts curriculum for Deaf students in a bilingual (American Sign Language and English) educational setting. It examines the implementation of writing workshops in three elementary classrooms in a school for Deaf students. The typical steps of preparing/planning, drafting, revising, editing, and publishing were carried out by all students in both languages to create stories and produce final products in both videotaped American Sign Language and written English. The effective practice of writing workshop was adapted to meet the learning needs of Deaf students by including visual processing, meaning-based teaching strategies, and bilingual methods. By having opportunities to create and revise stories in their first language (ASL), students experienced an increased sense of ownership of their work and developed some of the metalinguistic skills that are essential to becoming effective writers.

Cet article décrit la mise en œuvre d'un élément d'un programme d'études adapté pour les élèves sourds dans un contexte éducatif bilingue (le langage gestuel américain - ASL, et l'anglais). Plus précisément, on y discute la mise sur pied d'ateliers d'écriture dans trois classes du primaire dans une école pour élèves sourds. Les élèves ont suivi les démarches typiques - préparation et planification, rédaction d'une ébauche, révision, édition et publication - pour créer des histoires écrites en anglais écrit et enregistrées sur bande vidéo dans le langage ASL. Afin de répondre aux besoins des élèves sourds, l'atelier d'écriture avait été adapté, notamment en y ajoutant un traitement visuel, des stratégies d'enseignement basées sur le sens, et une méthodologie bilingue. L'occasion de créer et de réviser leurs histoires dans leur première langue (ASL) a développé chez les élèves des habiletés métalinguistiques essentielles à la rédaction ainsi qu'un meilleur sens d'appropriation de leurs travaux.

\section{Introduction}

Literacy is essential for success and an enhanced quality of life in our society. It is estimated that 2-3\% of Canadians are Deaf, and most of this group have inadequate literacy skills (Schein, 1996). (Throughout this article deaf refers to the audiological condition of not hearing, and Deaf refers to deaf children 
and adults who share a language [ASL] and a culture.) This prevents most Deaf people from attaining postsecondary education (Carver, 1991), limits their opportunities for employment (Carbin, 1996), and results in a loss of human potential. Deaf people are disadvantaged not because they cannot hear, but because they cannot read and write. This study suggests that one way of addressing the literacy crisis in the Deaf community is to refine and adapt language arts curricula for Deaf students to incorporate visual language processing, meaning-based strategies, and bilingual teaching principles. Specifically, this study examines the adapted implementation of a familiar language arts activity, writing workshop, to incorporate both American Sign Language and English stories with Deaf students in a bilingual educational setting.

The question of how best to promote literacy in deaf children has long frustrated teachers. From the beginnings of English literacy instruction, which primarily emphasized the use of amplification (hearing aids) to develop speaking and listening skills, to the development of simultaneous communication (speaking and signing at the same time) in the 1970s, the overall reading level of deaf high school graduates did not increase beyond the level of grade 4 (Moores, 1987). However, one group of deaf children, those with Deaf parents, consistently scored higher on tests of English reading skills than their deaf peers with hearing parents (Trybus \& Jensema, 1978). These children had the advantage of learning their first language through consistent and accessible exposure to proficient language models. Even though that language, American Sign Language (ASL), was different from English, it appeared to facilitate their abilities to learn written English as a second language (Hoffmeister \& Wilbur, 1980). These observations suggested to educators that deaf education should be considered a form of bilingual education, where deaf children learn ASL as a first language and English is introduced as a second language (Strong, 1988).

The promise of a bilingual approach to educating Deaf students has not been fully realized, partly because it requires a shift from viewing Deaf people as disabled to viewing them as belonging to a distinct linguistic and cultural group (Lane, 1992), and partly because bilingual education with Deaf students differs from spoken-language bilingual programs in several ways (Evans \& Seifert, 2000). These differences include the language modes (signed and written), with only one language (English) having a written form, and students' arriving at school with varying levels of development in their first language. These differences indicate that the principles of spokenlanguage bilingual teaching cannot be directly applied to educating Deaf students.

In particular, the inconsistent language exposure and background of deaf children before entering school differs from both bilingual education in heritage languages and bilingual education in second-language immersion 
programs. Among children born deaf, fewer than 10\% come from families with even one Deaf parent or older Deaf relative (Meadow, 1972; Trybus \& Jensema, 1978). For most families, encountering deafness is generally unexpected and traumatic. The parents and siblings of deaf children seldom have the signed language communication skills required to provide these children with immediate access to the acquisition of a natural language, a circumstance that limits access to the family's cultural knowledge and resources. Initial emphasis on amplification to maximize hearing abilities and develop speech skills may delay or limit the deaf child's acquisition of symbolic, meaningful language. Bilingual programming for these children, therefore, requires establishing a first-language foundation to facilitate an understanding of basic concepts, social interaction, and general communication skills.

\section{Theoretical Framework}

In this study a bilingual approach is applied to educating Deaf students who are learning ASL as their first language and English as a second language in written form. Applying a bilingual model to the education of Deaf students involves viewing Deaf people from a cultural perspective. This includes recognizing ASL and English as different and distinct languages and valuing both of them equally, developing pride and identity in being Deaf, exposing students to Deaf role models and peers, and addressing issues and conflicts with cultural sensitivity and awareness (Evans, Zimmer, \& Murray, 1994). It also implies that Deaf students are learning ASL as their first language and learning English as a second language, usually in written form. There is now growing evidence from case studies (Evans, 1998; Schleper, 1992; Wilcox, 1994) and the ongoing work in Sweden and Denmark (Mahshie, 1995; Svartholm, 2000) to indicate that appropriately adapting the principles of bilingual teaching is the key to successfully developing age-appropriate literacy skills in Deaf students.

When children, hearing or deaf, do not learn language or other concepts from natural exposure and stimulation, there is a tendency among educators to teach more explicitly (Rhodes \& Dudley-Marling, 1988; Stires, 1991). Historically, programs for teaching Deaf students to read have emphasized the mechanistic features of language because they are easier to teach (Livingston, 1997). Basal reading programs for deaf students are readily available, and these carefully introduce text containing limited vocabulary and sentence structures and then gradually add new words and structures as the child progresses (Quigley \& King, 1981). This explicit teaching process involves imposing structures, incorporating drill and practice, and breaking down the information into smaller but also less meaningful chunks. If explicit teaching methods are used excessively, they contribute to creating highly dependent learners, something that is often found in deaf students (Marschark, Lang, \& 
Albertini, 2002). Another problem with structured reading programs is that they do not provide children with exposure to real literature as used in naturally occurring contexts. Many of the context cues are eliminated to avoid complex grammar or vocabulary (Ewoldt, 1984, 1987). Reducing deaf students' opportunities to use context to determine meaning may be eliminating precisely their strength in reading comprehension (Yurkowski \& Ewoldt, 1986). In short, these programs frequently develop stories that children may be able to read, but rarely are able to connect to their own experiences and make truly meaningful (Wells, 1986). In this study the naturalistic and meaning-based strategy of process writing was adapted to include process signing as well. This involved students' planning, drafting, revising, and publishing their stories in ASL on videotape, just as they would process written English stories on paper.

The unique combination of bilingual and meaning-based theories provides a framework that views Deaf people from a cultural perspective, incorporates the features of visual language processing, and builds on the common conceptual foundation to develop literacy skills in both languages, English and ASL.

\section{Bilingual Language Arts Curriculum}

Although the focus of this article is the implementation of one aspect of the bilingual language arts curriculum-writing workshop-some discussion about the principles and procedures guiding overall language arts instruction is needed.

The Manitoba Language Arts Curriculum Framework (Manitoba Education and Training, 1998) was used as the basis for developing a bilingual and meaning-based curriculum for Deaf students. The five general outcomes of this framework are broad enough to include the skills of viewing (or visually comprehending) and signing (or visually expressing) language in ASL. Table 1 provides a summary of the curriculum framework with the general outcomes (GO) stated across the top, and a brief list of the skills included in these outcomes in the columns below. Because the emphasis is on language, the general outcomes of the language arts curriculum are easily adapted to a bilingual approach: these outcomes can apply to skills in any language, including a signed language such as ASL. It is important to emphasize that ASL is not used with Deaf students solely as a means to facilitate the development of spoken/written English skills. Bilingualism must be valued as an end in itself: anyone can benefit from knowing an additional language, including a signed language. This is true for hearing students, students with oral/auditory skills, students with cochlear implants, and students with no speech skills at all. For this reason the bilingual curriculum includes language arts instruction in ASL as well as English. 
Table 1

Manitoba Language Arts Curriculum Framework

\begin{tabular}{|c|c|c|c|c|}
\hline $\begin{array}{l}\text { GO1 } \\
\text { Explore } \\
\text { thoughts, } \\
\text { ideas, } \\
\text { feelings, and } \\
\text { experiences }\end{array}$ & $\begin{array}{l}\text { GO2 } \\
\text { Comprehend } \\
\text { and respond } \\
\text { personally and } \\
\text { critically to oral, } \\
\text { literary, and } \\
\text { media texts }\end{array}$ & $\begin{array}{l}\text { GO3 } \\
\text { Manage } \\
\text { ideas and } \\
\text { information }\end{array}$ & $\begin{array}{l}\text { GO4 } \\
\text { Enhance clarity } \\
\text { and artistry of } \\
\text { communication }\end{array}$ & $\begin{array}{l}\text { GO5 } \\
\text { Celebrate and } \\
\text { build community }\end{array}$ \\
\hline $\begin{array}{l}\text { 1.1 Discover } \\
\text { and explore }\end{array}$ & $\begin{array}{l}2.1 \text { Use } \\
\text { strategies and } \\
\text { cues }\end{array}$ & $\begin{array}{l}\text { 3.1 Plan and } \\
\text { focus }\end{array}$ & $\begin{array}{l}\text { 4.1 Generate } \\
\text { and focus }\end{array}$ & $\begin{array}{l}\text { 5.1 Develop and } \\
\text { celebrate } \\
\text { community }\end{array}$ \\
\hline \multirow[t]{3}{*}{$\begin{array}{l}1.2 \text { Clarify } \\
\text { and extend }\end{array}$} & $\begin{array}{l}2.2 \text { Respond to } \\
\text { texts }\end{array}$ & $\begin{array}{l}3.2 \text { Select } \\
\text { and process }\end{array}$ & $\begin{array}{l}4.2 \text { Enhance } \\
\text { and improve }\end{array}$ & $\begin{array}{l}5.2 \text { Encourage, } \\
\text { support, and } \\
\text { work with others }\end{array}$ \\
\hline & $\begin{array}{l}2.3 \text { Understand } \\
\text { forms and } \\
\text { techniques }\end{array}$ & $\begin{array}{l}\text { 3.3 Organize, } \\
\text { record, and } \\
\text { assess }\end{array}$ & $\begin{array}{l}\text { 4.3 Attend to } \\
\text { conventions }\end{array}$ & \\
\hline & & & $\begin{array}{l}\text { 4.4 Present } \\
\text { and share }\end{array}$ & \\
\hline
\end{tabular}

One of the key concepts guiding the bilingual language arts curriculum is that language, not speech, is the foundation for literacy learning. This concept is strongly supported in the general outcomes of the Manitoba language arts curriculum, despite implementation procedures involving connections between print and speech. This issue of connecting speech and print is addressed by the second key concept underlying the bilingual language arts curriculum: that literacy involves making and sharing meaning. If speech is meaningful to children, whether they are hearing or Deaf, it can be used to mediate print; however, if speech is not meaningful to a Deaf child, another mediator such as signed language must be used to make the connection. Meaning drives learning, and as teachers we must find ways to link unfamiliar symbols such as language in print with symbols that are familiar and meaningful to children (Harwayne, 2001).

The third key concept guiding the bilingual language arts curriculum is the importance of establishing a first-language base: this is the foundation for all Deaf bilingual programs. The primary objective is to facilitate the normal acquisition of linguistic, cognitive, and social structures through an accessible first language, and then to build the skills of academic learning and literacy on this foundation. However, the reality is that many Deaf students enter school without an established first language in either signed or spoken form. Therefore, if Deaf students enter school without an established language base, this must be the focus of education before proceeding with other curricular areas. 
The final key concept is that students learn to transfer skills from one language to the other through the development of metalinguistic awareness. Cummins (1984) proposed that the two separate language systems of bilinguals are linked to a common conceptual core, suggesting a common underlying proficiency. This implies that experience with either language can promote the proficiency underlying both languages. The common proficiency does not exist at the surface levels (pronunciation, grammar, vocabulary) of the first and second languages, but at the deeper conceptual levels (knowledge, thinking skills, literacy strategies). This implies that although Deaf students need to be taught the specific vocabulary and grammar of English, their English literacy development can be facilitated by building on existing concepts, knowledge, and learning strategies acquired in ASL.

\section{Procedure}

In the past two decades there has been an emphasis in research related to teaching writing to define the writing process. As a result a shift has occurred in instructional methods from focusing on the written product to emphasizing the process of writing itself (Bright, 2002). The commonly agreed-on steps of this process include preparing/planning (prewriting), drafting, revising, editing, and publishing. Authors begin the process by planning, or thinking about what to write; brainstorming ideas; and considering their audience, purpose, and form of writing. Drafting involves getting the ideas down on paper (or on the computer screen) without concern for the accuracy of formal structures like spelling and punctuation. Authors will typically get feedback from others to assist them with the revising stage, where changes (additions, deletions, reordering) are made to the flow and content of the writing. The next part of the process is editing; this involves making corrections to the conventions of writing: grammar, spelling, and punctuation. The final step is taking the writing to a formal form through publication or presentation to an audience. These steps are not necessarily sequential, and writers move back and forth between them as they construct their work (Peterson, 1995).

This description of the writing process is the foundation for implementing writing workshop in the classroom. It allows teachers to create an environment where students are writing for real purposes, becoming independent in their writing, and participating actively in the learning process. These same principles guided the implementation of the process in three classrooms at a school for Deaf students. The key adaptation was that students proceeded through the steps of writing workshop to produce stories in both ASL (on video) and English (on paper). This adaptation resulted in the implementation of process signing to create videotaped stories in ASL. This process-oriented method for writing activities is used in Swedish schools for Deaf students, where teachers indicate that the video 
camera serves as pen and paper to record students' rough drafts, to allow for review (by self and others), and to make revisions (Foss Ahlden \& Lundin, 1994). Some students also used the ASL versions of the stories to develop their written English stories. The method of making explicit comparisons and translations between the two languages was found to be effective in earlier studies with Deaf students. For example, Neuroth-Gimbrone and Logiodice (1992) videotaped students expressing story content in ASL and then had them produce transcripts of these videotapes to form the basis for their English writing. Working in the two languages builds on the students' underlying knowledge, ideas, and sense of literacy to facilitate their use of the different surface structures (grammar and vocabulary).

Specific implementation in this study involved working with three classrooms (one grade 4 and two grade 5 classes) daily for approximately one hour (some sessions were 90 minutes in length) over a three-week period. During these sessions all students were involved in writing workshop, which included mini-lessons with the whole group; independent writing time; individual conferencing with the researcher, the teacher, a peer, or the ASL specialist; and sharing written or signed stories with the class. In each of the classes, prewriting activities were conducted to help students generate ideas and develop background information on a particular topic. These initial activities included both English print materials and ASL resources. Following the prewriting stage, students were required to develop a story plan in either print (point form) or picture format. When the plan was completed, students were able to choose whether to draft their story in ASL (recorded on video) or in written English. Students then completed the revising, editing, and publishing stages in that same language before proceeding through these final stages again using the other language. All students produced final products in both written English and videotaped ASL. Table 2 provides a summary of how the process of writing workshop was adapted to include process signing and the creation of stories in both written English and videotaped ASL.

\section{Participants}

The primary participants in this study were the 14 Deaf students in three classrooms at a specialized school for the deaf, ranging in age from 9 to 11 years. Although these students covered only two grade levels (6 students in grade 4 and 8 students in grade 5), the writing workshop was implemented in three classes because the grade 5 students were separated into two groups of four for language arts instruction.

The students' written English skills were assessed by applying the Kendall Writing Levels (French, 1999) to independent writing samples collected following the presentation of a wordless picture book. The Kendall Writing Levels include eight levels, generally classified as emerging literacy (Levels 
Table 2

Curriculum Adaptation re: Writing Workshop

General Outcome 4: Enhance clarity and artistry of communication. Activity: Process Writing (Signing)

\begin{tabular}{ll}
\hline $\begin{array}{l}\text { Description } \\
\text { - Preparatory work (ideas, planning, } \\
\text { brainstorming) }\end{array}$ & $\begin{array}{l}\text { Adaptations for Deaf Students } \\
\text { - Introduce Process Signing to produce texts } \\
\text { in sign language (add language to their }\end{array}$ \\
- First draft (rough) & thoughts) \\
- Feedback (response from peers/teacher) & - Combine process signing and process \\
- Revising (content, style, form) & writing to produce texts in two versions \\
- Feedback (peers/teacher) & (written and signed) \\
- Editing (proofreading, spelling, & - First draft can be written, drawn, or signed \\
punctuation, choice of words) & - Connect print to pictures or signs \\
- Publication (sharing) & - Each version has a "published" form (print \\
- Evaluation (grading) & or video) \\
\hline
\end{tabular}

1, 2-preschool/kindergarten), beginning literacy (Levels 3, 4, 5-kindergarten to grade 2), developing literacy (Levels 6, 7-grades 2-4), and maturing literacy (Level 8-grades 4-6). The writing abilities of the students in this study ranged from Level 3 to Level 7 . Of the six grade 4 students, one was writing at grade level with a Level 6 rating, but the others were assessed at the beginning literacy levels (one at Level 5, three at Level 4, and one at Level 3 ). With the grade 5 students, four were approaching age-appropriate writing at the developing literacy levels (one at Level 7, three at Level 6), but the remaining four students were still at the beginning literacy levels (two at Level 5, one at Level 4, and one at Level 3).

A similar range of language abilities was reflected in the students' ASL skills. These were measured by analyzing a videotaped language sample of the students describing the same wordless picture book as with the written sample, as well as the administration of an ASL classifier comprehension task. In general, the language sample activity revealed that students with higher English writing levels also produced more elaborate and grammatically complex ASL stories, and those with lower English writing levels produced basic ASL versions, with the exception of two grade 5 students. With these two students, although their English writing skills were at the beginning literacy level (Levels 4 and 5), their ASL stories included a variety of sentence types, grammatical markers, and narrative features.

The ASL classifier comprehension task required students to look at pictures of objects with a variety of features and then select the correct signed description (ASL classifier) from four possible options presented on video by a native ASL signer. Due to the complexity of the task itself, two practice items were administered before the 10 test items to ensure that the students understood the task. One grade 4 student was unable to complete the prac- 
tice items and the task was discontinued. The remaining grade 4 students indicated a developing comprehension of ASL classifiers, with one student scoring 4/10 correct, three students scoring 5/10 correct, and one student $7 / 10$ correct. Three of the grade 5 students were approaching mastery of classifier comprehension with scores of $9 / 10$ and $8 / 10$ correct, another three were developing with scores of $6 / 10$ and $5 / 10$, but two grade 5 students were still struggling to acquire this structure and received scores of only $3 / 10$ correct.

The purpose of this brief summary of the students' language skills is to show how these classrooms reflect the typical pattern and range of abilities that are present in most classrooms of deaf children. In general, there are a few students whose language skills in both English and ASL are developing age-appropriately; almost half the students are delayed in both English and ASL development; and then a few students show a discrepancy between their skills in one language compared with the other, with their ASL skills usually exceeding written English development.

Although the researcher was primarily responsible for planning and directing the activities of writing workshop in the classrooms, the three teachers and the school's ASL specialist also participated in and facilitated some of the teaching sessions. The three teachers were all hearing, but two of them had over 12 years' experience teaching Deaf students and were fluent users of ASL. The third teacher had recently graduated from a preparation program for teachers of deaf/hard of hearing students, and this was her first year teaching in the school. Her skills in ASL were still developing. The teachers collaborated with the researcher to help plan the topics and writing goals for the students, and they were present throughout all the teaching sessions to conference with students or assist them individually as needed.

The ASL specialist was a Deaf woman with 10 years' experience in her position, which included teaching ASL to groups of students and staff, as well as assessment and remediation of ASL skills with individual students as required. Her primary involvement with the study was to provide students with feedback about the ASL versions of their stories and to facilitate the videotaping of the final drafts in the studio.

\section{Role of the Researcher}

The researcher played a key role in implementing the writing workshop procedures in each of the three classrooms; however, both planning these activities and selecting appropriate writing topics and goals were determined in collaboration with the classroom teachers. Literacy development in Deaf students has been the primary focus of the researcher's seven-year academic career, and before that she worked for over 10 years as an educator of Deaf children in both school and preschool settings. The researcher is hearing, and although she is fluent in ASL, she also drew on videotaped 
resources and invited guests from the Deaf community and Deaf staff in order to present the students with native signing role models during the teaching sessions.

In order to keep the roles of teacher and researcher distinct, all classroom sessions were videotaped for later analysis. This allowed the researcher to focus on teaching and the immediate needs of the students, rather than data collection, during the instructional times. Copies of student work at all stages of progress (drafts, revisions, final product) were also made for both written and videotaped materials to help provide context for future data analysis.

\section{Data Analysis}

The qualitative design of this descriptive study involved data collection in the form of field notes of classroom teaching sessions (created from notes kept by the researcher immediately following the teaching sessions and then elaborated on through the viewing of the videotapes), transcripts of interviews with the three teachers, individual language assessments and selfevaluation of the 14 students, and a variety of samples of student work. The data were systematically analyzed and organized into recurring topics and themes. As themes were strengthened from various data sources, contradictory evidence was specifically sought to ensure the consistency of all information.

\section{Findings and Discussion}

The data collected included videotapes of all classroom sessions, teacher interviews before and after the classroom intervention, individual student interviews and assessments (ASL and written English), and samples of students' work. Systematic analysis of the data revealed three primary themes: the role of ASL in developing English literacy skills, the critical nature of metalinguistic awareness in the writing/signing process, and the significance of a sense of ownership in one's work, which is discussed from the perspective of the teachers, as well as four that are discussed from the perspective of the students: the importance of self-confidence, the development of student independence, application of knowledge from ASL, and once again the sense of ownership.

\section{Teachers' Perspectives}

It is interesting to note that all three teachers expressed a lack of information about the writing process or writing workshop as part of their professional preparation programs to become teachers of deaf students. One teacher indicated that it was part of her undergraduate program in general education, but not her master's in deaf education. This may reflect the attitude that deaf students require more structure and direct teaching. It may also be related to the educational emphasis on the deficit perspective on deaf stu- 
dents, where the goal is always to develop speech and listening skills. As one teacher stated, "There was much more emphasis on learning about audiology and learning about speech, and learning about language and how language goes together but not on the writing process."

Knowledge of ASL. The teachers had much to say about how students' knowledge of ASL influenced their English literacy skills. In general, they all indicated that deaf children are at a disadvantage in accessing information around them because they do not receive the same kind of immersion and continual auditory exposure to language that hearing children do.

It is very difficult for them, often because they don't have that auditory feedback all the time of hearing English as a first language and understanding how it goes together and what words come in what order, and how to put all those tiny words like to and the and is ... it is very, very difficult and we have to teach that.

The importance of early communication in the home was seen as critical in resolving this issue; "I understand more the why now [of low academic functioning] when I see the new kids that are coming in with no language and having no language at home." The teachers emphasized the importance of exposure to ASL to establish a language base, develop background knowledge, and facilitate communication and learning:

I think if they can get a strong ASL background then it provides a foundation when they're writing English. A couple of them have the stronger ASL background and they also have the stronger English writing as well.

Although the teachers felt a sense of having to make up for the lack of language experiences at home, they were also overwhelmed by this responsibility; "And how can they possibly get enough—to just come to school for six and a half hours-we're just not enough." The teachers indicated that several instructional options were possible for students arriving at school without an appropriate language background, but incorporating the bilingual teaching principal of establishing a first-language base before expecting students to learn English was considered essential.

The teachers did indicate that students' knowledge of ASL at times interfered with their writing in English. One teacher indicated that this first stage of "writing in ASL" was an important part of the process: "Oh, that's ASL, not English, but a lot, at this point, I just leave. I'm trying to encourage them just to write." The goal for the teachers was to make sure that the text was meaningful, whether the students were writing it themselves or reading what others had written. The process of moving from thinking and writing in ASL to writing in English was considered their role as teachers: "I mean, 
often we'll see a written work and it's written as ASL, and it takes a long time to break that and teach English as separate from ASL."

Metalinguistic awareness. The goal is to have students reach an understanding of the two languages and the ability to compare and switch between them: "I think the play of language is back and forth between the two and I think that a person who's truly literate in both, I think, can see the comparisons and move back and forth between the two languages." This idea of keeping the languages separate, but understanding the similarities and differences between them is how the teachers defined bilingual education with deaf students, "So you're developing ASL skills, as well as developing written English skills at the same time and being able to see comparisons between the two."

To accomplish this goal of bilingualism requires metalinguistic skills, or the ability to analyze and talk about language. Teaching writing through writer's workshop incorporates the skills of metacognition and self-evaluation in order to develop students' abilities to think analytically and critically. All three teachers in this study indicated that in their experience, deaf students lacked these skills. For example, "I have never seen a Deaf child being able to self-edit" or "you're saying, 'What did you think of this story?' and they're going, 'I don't know,' because they haven't a foggy clue how to even start thinking about analyzing."

The teachers did feel that the ability to self-reflect and self-evaluate was critical to being good writers; "Maybe if you don't have the metacognitive skills to self-evaluate, in many ways you can't do that about your writing or your signing." As a result, the teachers also felt that it was their role to teach these skills:

You can have kids who can say, "I don't like your story," but that's not enough. You have to be able to say, "I didn't understand when this happened." And we have to teach that, and it can be a long process. You have to teach them to be critical in a positive sort of way.

Although not all the teachers were clear as to why deaf students were lacking in metacognitive abilities, one teacher suggested language skills and limited communication opportunities as a possible reason:

Half of our kids don't get beyond the literal question and answer. And I think it's a lack of language, you know, a lack of that discussion at home. If you think about how many of their parents ask these kids their opinion about things-what do you think about this? That dialogue is not happening, especially when parents are struggling to give them the main information about getting dressed, feeding, and homework.

On a more positive note, the teachers did have specific suggestions for how to improve this situation and facilitate students' metacognitive, metalin- 
guistic, and self-evaluation skills. For example, "having a system or having a checklist helps them, not getting them to just edit," or "I find that if you can break down the skills for them-this time when you go through I want you to make sure that you have all the punctuation, all the capitals." The teachers indicated that the key to building metalinguistic and metacognitive skills was to do so gradually, beginning with having the students identify what they liked about a piece, then moving to considering how it could be improved.

Working with peers was also considered valuable:

So it's not always coming from the teacher saying, I don't get this or that doesn't make sense, or that English structure isn't right. If it comes from their peers then they seem to take it a little bit easier.

In summary, the teacher's perspectives reflected the literature in terms of the needs and benefits of a bilingual approach to educating deaf students, and more specifically teaching them to write.

Sense of ownership. All three teachers noted the importance of giving students a choice so that they could follow their own interests, become excited about writing, and develop a positive attitude toward it. Although some guidelines for stories were imposed by the teachers in each classroom, the students were still able to make choices throughout the process. For example, in the grade 4 classroom, guidelines were given about the story topic (animals) and language structure (stories had to include a Wh- question); however, students were free to choose whatever animal(s) they wanted, the type of question that fitted their ideas, and whether to use the question once or repeatedly in their story. In the grade 5 classrooms, topics were not specified, but students were required to incorporated dialogue between characters or some kind of written correspondence (notes, letters, e-mail, etc.) in their stories. Thus the strategy of bilingual writing workshop allowed for specific teaching of language structures, but also provided the students with many opportunities to exercise their own choices.

Teachers also shared the concern that there was never enough time to teach background information and basic skills and to focus on the process rather than the product of writing. This specific concern was addressed through the implementation of bilingual writing workshop because it allowed the students to be creative in their first language rather than feel stifled by their inadequacies in written English. This facilitated their overall sense of confidence and interest in their stories. For some students, the ability to refer to the recorded version of their story in ASL allowed them to be more independent in writing the English version. When students are able to work independently, it frees teacher time and further builds students' self-confidence. 
Activities that allowed students some choice and had a purpose were considered by the teachers as the most effective and motivating for students, "I find that just getting excited about writing, like some topic that just really gets them so excited that they just can't wait to put down the words on paper. I think that's what motivates them."

Clearly the activity or topic that works will not be the same for every child: it must be their personal interest and their choice. The teachers also discussed another point related to the purpose of the writing and whether it was meaningful to the students or not.

I think children often need to have a purpose for writing ... there's not may children I've ever seen that just write because they want to write, whether they're Deaf or hearing. But I think too that if it's their idea,

they're more, much more motivated than when it's my idea.

The value of establishing language skills in ASL and using this knowledge to build skills in English was seen as critical to maximizing the potential of the students' learning and literacy development. The bilingual writing workshop linked directly with this concept of building on students' existing skills in ASL. However, the process also enabled teachers to see how classroom work in ASL must go beyond the conversational level to include analysis of linguistic features, comparison of structures between languages, and critical thinking skills. For example, the students' knowledge of shoulder-shifting in ASL to indicate dialogue between characters was highlighted to help them understand the appropriate use of paragraphs and quotation marks to represent written dialogue in English. Only through this kind of linguistic analysis and metalinguistic awareness were students able to apply their knowledge of ASL to facilitate written English skills.

\section{Students' Perspectives}

Although the ultimate goal for implementing bilingual writing workshop in classrooms of Deaf students was to improve the students' English literacy skills, it was not expected that a measurable difference in their writing skills would be noted following only one cycle of the process over a three-week period. Therefore, it was necessary to measure growth in less structural ways, such as self-confidence, independence, application of knowledge from ASL, metalinguistic skills, and a sense of ownership.

Self-confidence. Confidence plays an important role in learning. The relationship between confidence and learning is explained through the concept of self-efficacy: one's beliefs about one's ability to perform a specific task. It is important to specify that beliefs, rather than actual abilities, are the significant factor in this equation. An individual's self-efficacy in a given situation will influence interest, motivation, and perseverance in the task at hand and will also affect further choices and behaviors for related endeavors 
(Bandura, 1997). For this reason, establishing a positive attitude toward writing can influence students' ongoing learning in this area. The implementation of bilingual writing workshop contributed to the students' self-confidence by allowing them to make choices, providing them with opportunities to practice skills actively, and presenting them with numerous role models.

Active learning is one of the most influential factors in self-efficacy (Jepson et al., 2005). Through having the opportunity to learn and practice writing skills, students are able to develop self-efficacy in the discipline of writing. Models also serve as a source of learning and development of self-confidence, particularly models who are most similar to the students themselves (Bandura, 1997). The bilingual writing process incorporated interaction with Deaf peers and Deaf adults to take advantage of and build on this principle of learning.

Independence. As several of the teachers observed, more independent writing was facilitated by the opportunity for students to use their ASL stories to help them write the English versions. There is a tendency for deaf students to become highly dependent learners (Marschark et al., 2002); therefore, finding strategies that reduce this tendency while still supporting the languagelearning needs of deaf students is an important contribution. The students who benefited the most from watching the video of their ASL story as they were writing their English story were those with a large discrepancy between their ASL and English skills. And even students who did not directly refer to their ASL stories while writing the English versions demonstrated some influence from their knowledge of ASL. This was evidenced by increased story length, more complex vocabulary, and elaborated story features such as description of setting and introduction of characters. These elements reflect improvements in students' writing through the supported writing process, not necessarily in their independent writing; however, it is predicted that ongoing use of bilingual writing workshop could contribute to such gains in independent writing.

Preliminary findings from the second year of implementing bilingual writing workshop with these students indicated that independence was developing, particularly in their revising skills. Students were noted to revise in ASL more readily than in English; however, through the use of computer programs like spell and grammar checks, they were improving in their revision in English as well. Initially, the analysis of their work focused more on production and mechanics such as signing smoothly, making eye contact, and using appropriate expression, but after several cycles through the writing workshop process, their feedback focused on the story content itself. In general, the students looked forward to writing workshop and expressed enthusiasm and interest in creating stories. Communities of writers have 
developed in the classrooms, where students are able to provide and accept more constructive criticism and ask each other for help.

Knowledge of ASL. An essential component of a bilingual approach to literacy learning is to take advantage of the language proficiency underlying both the first and second languages. As indicated above, this does not mean that learning vocabulary or grammar structures in ASL will automatically transfer to an understanding of these structures in English: Deaf students still need to be taught the phonology, morphology, and syntax of English. However, recent studies support the view that proficiency in ASL can influence the English writing abilities of deaf students. A recent study distinguished deaf students with low, moderate, and high ASL proficiency and contradicted some of the earlier findings about the limited English vocabulary skills of deaf students. Singleton, Morgan, DiGello, Wiles, and Rivers (2004) compared deaf elementary students and hearing ESL students on a written composition task. Results indicated that although the deaf students with low ASL proficiency produced formulaic sentences with limited and high-frequency vocabulary items as predicted, the deaf students with moderate and high ASL proficiency demonstrated non-formulaic writing that incorporated novel, low-frequency vocabulary. All deaf students, regardless of ASL proficiency, differed from the ESL students in less frequent and appropriate use of function words. These findings suggest that English language instruction with deaf students should incorporate strategies that build on their semantic knowledge in ASL. Other studies have suggested that strategies to link English words with Deaf children's network of ASL concepts are an effective way to expand word knowledge and facilitate reading comprehension (McAnally, Rose, \& Quigley, 1999). Research has emphasized the value of making connections between Deaf students' knowledge of concepts in ASL with print, either through signs (Bailes, 2001; Gallimore, 1999) or finger spelling (Padden \& Ramsey, 2000).

A metalinguistic understanding of the grammatical features of ASL can provide Deaf students with the tools and understanding they need to analyze and evaluate written English skills. By implementing process signing in creating ASL stories, Deaf students increased their metalinguistic awareness of language structures and gained an understanding and appreciation of applying these to the context of writing. For example, one student indicated that he wanted to videotape his ASL story again, because while reviewing it, he had noticed his incorrect use of verb direction (similar to subject-verb agreement in English) and the fact that he had repeated himself on several occasions. These kinds of observations occurred frequently among the students and reflected how increased understanding and correct use of linguistic structures can clarify one's message, as well as emphasizing the value of revising and not being satisfied with a first draft. 
A common response to revising written drafts by both hearing and deaf children is to state, I'm finished. Why do I have to do it again? Gently pushing students to review their work, share it with others, and get suggestions for how it could be improved helped to establish self-evaluation skills and an understanding of the writing process. Developing an appreciation for the process of creating stories in ASL was something that both teachers and students had to learn. Although students understood that their initial recordings were drafts, they frequently wanted, and needed, to rehearse their stories before going in front of the camera. These rehearsals occurred in various settings: in isolation, in front of a mirror, or with teachers or other students as an audience. The editing and revising processes in ASL were also different from those in written English in that changes could not be made to single words or phrases, but rather involved an entire retaping of the story. This required Deaf students to hold all the story elements and feedback in mind in order to produce the final version effectively.

Ownership. Intrinsic to all children is the need to feel honored and appreciated for their efforts and to have the work they produce be respected by others. When children are honored for their gifts, they develop a sense of ownership for their work and will want to share it with others (Atwell, 1998). For the students in this study, like many deaf students, writing was often an exercise imposed on them by the teacher. The original story idea may have been theirs, but by the time it was manipulated to fit a story plan and corrected for sentence structure and spelling, the spark of excitement and sense of ownership had been extinguished. Deaf children are often taught to write by using sentence patterns, starting with simple structures such as noun + verb, and expanding to more complex patterns. These contrived types of sentences may provide students with a good understanding of grammar, but can cause them to focus on the sentence pattern itself and lose the wonderfully imaginative idea they wanted to write about in the first place. By expressing themselves in their first language, ASL, students could mention many of these imaginative ideas in their stories, and as a result they also maintained ownership of them. This was particularly evident when students were sharing their stories with each other in the classroom. Their pride was evident in their beaming smiles, rapt attention, and motivation to participate: some of them were literally bouncing out of their chairs with enthusiasm.

\section{Conclusion}

Although writing workshop was a procedure that had previously been implemented in all three classrooms, the piece that was different in this project was producing a parallel story in ASL. From the point of view of teachers and students, this element was significant in that all language skills were acknowledged and valued, contributing to increased confidence, creative 
expression, metalinguistic awareness, self-evaluation, and a sense of ownership in the students.

Metalinguistic skills do not depend on being able to hear, but they do depend on having opportunities and experiences that facilitate planning, monitoring, and evaluating (Andrews, Leigh, \& Weiner, 2004). The teachers indicated that many deaf children from hearing families where communication was limited were not developing metalinguistic skills incidentally and needed to be taught these skills more explicitly.

This study clarified the strong relationship between language and literacy skills in ASL and English and the need to develop both at an academic level. The relationship is not causal: the surface structures (phonology, morphology, syntax) of the two languages do not map directly onto each other, but one can facilitate the other through the development of deeper structures (concepts, thinking skills, metalinguistic awareness). The students were able to generate and express ideas for characters and plots in ASL, and these were maintained as their own through the translation process into written English. In order for Deaf students' knowledge of ASL to benefit their English literacy development, they must learn to use ASL for higher cognitive functioning, in decontextualized situations, and at a metalinguistic level. These processes of analysis and evaluation can then be applied to help them decipher the code of written English.

The opportunity to have a video-recording of their stories in ASL allowed students to refer back to what they had signed and helped them put their ideas into written English: "like when Corey [pseudonym] was working with the TV, I think that really helped him with his writing." It also facilitated more independent work on the part of some students: "It was nice having the movie and especially having the camera there, so they could go back and forth and just do a big chunk on their own."

The implementation of a bilingual approach to writing workshop facilitated a balance between language teaching and creative expression. As one teacher commented,

They entered into the project with a great deal of enthusiasm and that was really nice to see, because I have some fairly reluctant writers. They were excited about it and I think that's always a good place to start in writing.

Most of the students were able to express themselves more freely and creatively in ASL, and as a result their ASL stories were more elaborate and embellished than the English versions.

The teachers agreed that providing students with the option of producing a story in ASL was valuable, but they also expressed some concerns about how adding this element complicated the logistics and extended the process. They questioned whether they would be able to implement this option 
without the benefit of additional personnel such as the researcher and of easily accessible video equipment. Implementing bilingual writing workshop requires cameras and televisions to be as available and accessible as pencils and paper in the classroom, for they are serving the same function: to record children's ideas.

This project demonstrated the importance of sharing and celebrating each other's work in developing pride, respect, and community in the classroom. When individuals have the opportunity to present in front of peers, they are motivated by the chance to gain respect, to have an effect on the community, and to receive recognition (Scardamalia \& Bereiter, 1994). Moreover, just as the presenter gains respect, the audience is valued for its input (peers' suggestions were often accepted more readily than teachers' suggestions), and this further builds pride and motivation.

The most significant effect that implementing an ASL option in the writing workshop had on the students was giving them ownership of their stories. This was expressed best by one of the teachers:

I often find that when these children write that they don't own the stories-it is something that I make them do. But somehow when it translated into ASL, it became their story. You could see the excitement on their faces and I think that they then loved their story more.

If one assumes that Deaf students have an established first language and that others in the environment can understand this language, then the process of adapting existing language arts curricula to accommodate the visual and bilingual needs of Deaf students is quite straightforward. Unfortunately, age-appropriate acquisition of a first language for deaf children is still a huge assumption in most cases, as is the assumption that educational settings will have teachers or other school personnel and peers who are fluent in a deaf child's first language, particularly if it is a signed language.

In addition to an established first language and others that can communicate in this language, there is also a need for teachers with fluency in the two languages of the bilingual program and with a good understanding of the cultural beliefs and values associated with each of them. Again, this is complicated and not easily attained. As well, there is a need to have texts available in both languages, and this involves both print and video media. Although many books and print media are available for students in English, collections of videotaped ASL materials are lacking.

The final component of a successful adaptation of language arts curricula is the creativity to adapt the best practices used with all children to fit the visual and language needs of Deaf students. This study provides an example of exactly such an implementation. In the context of a bilingual program for Deaf students, the best practice of writing workshop was adapted to meet the learning needs of these students. By being allowed to create and revise 
stories in their first language, students experienced a sense of ownership and began to demonstrate some of the metalinguistic skills that are essential to becoming effective writers.

\section{Acknowledgment}

This research project is supported by a grant from the Social Sciences and Humanities Research Council of Canada

\section{The Authors}

Charlotte Enns is an associate professor in the Faculty of Education in the University of Manitoba. Her primary research interest is the development of literacy skills in Deaf children.

Ricki Hall is the resource teacher in the Manitoba School for the Deaf, where she has taught in elementary-level classrooms for 15 years.

Becky Isaac is an itinerant consultant for deaf/hard of hearing students in northern and rural areas of Manitoba.

Patricia MacDonald has been a teacher in the Manitoba School for the Deaf for 20 years, and although for most of these years she has been teaching elementary-level students, she is now taking on the challenge of teaching at the junior-high level.

\section{References}

Andrews, J.F., Leigh, I.W., \& Weiner, M.T. (2004). Deaf people: Evolving perspectives from psychology, education, and sociology. Boston, MA: Allyn \& Bacon.

Atwell, N. (1998). In the middle: New understandings about writing, reading and learning (2nd ed.). Portsmouth, NH: Boynton/Cook.

Bailes, C. (2001). Integrative ASL-English language arts: Bridging paths to literacy. Sign Language Studies, 1(2), 147-174.

Bandura, A. (1997). Self-efficacy: The exercise of control. New York: W.H. Freeman.

Bright, R. (2002). Write from the start: Writer's workshop for the primary grades. Winnipeg, MB: Portage \& Main Press.

Carbin, C.F. (1996). Deaf heritage in Canada: A distinctive, diverse, and enduring culture. Whitby, ON: McGraw-Hill Ryerson.

Carver, S. (1991). Post-secondary and employment opportunities for deaf adults in Canada. In E.G. Wolf-Schein \& J.D. Schein (Eds.), Post-secondary education for deaf students (pp. 89-96). Edmonton, AB: Educational Psychology, University of Alberta.

Cummins, J. (1984). Bilingualism and special education: Issues in assessment and pedagogy. San Diego, CA: College Hill Press.

Evans, C.J. (1998). Literacy development in Deaf students: Case studies in bilingual teaching and learning. Unpublished doctoral dissertation, University of Manitoba, Winnipeg.

Evans, C.J., \& Seifert, K.L. (2000). Fostering ASL/ESL bilinguals. TESL Canada Journal, 18(1), $1-16$.

Evans, C.J., Zimmer, K., \& Murray, D. (1994). Discovering with words and signs: A resource guide for developing a bilingual and bicultural preschool program for deaf and hearing children. Ottawa: Child Care Initiatives Fund, Health and Welfare Canada.

Ewoldt, C. (1984). Problems with rewritten materials as exemplified by "To build a fire." American Annals of the Deaf, February, 23-28.

Ewoldt, C. (1987). Reading tests and the deaf reader. Perspectives, March, 21-24.

Foss Ahlden, H., \& Lundin, K. (1994). Language workshop in grade 3: A process-oriented working method in a bilingual school for the deaf. Orebro, Sweden: SIH Laromedel.

French, M.M. (1999). Starting with assessment: A Developmental approach to deaf children's literacy. Washington, DC: Gallaudet University Pre-College National Mission Programs. 
Gallimore, L. (1999). Teachers' stories: Teaching American Sign Language and English literacy. Unpublished doctoral dissertation, University of Arizona.

Harwayne, S. (2001). Writing through childhood: Rethinking process and product. Portsmouth, NH: Heinemann.

Hoffmeister, R., \& Wilbur, R. (1980). Developmental: The acquisition of sign language. In H. Lane \& F. Grosjean (Eds.), Recent perspectives on American Sign Language (pp. 61-78). Hillsdale, NJ: Erlbaum.

Jepson, P.J., Johnson, P.R., Brown, S.W., Lang, H.G., Laporta-Hupper, M., Monte, D., Scheifele, P.M., \& Babb, G. (2005, April). Classroom of the sea: Developing science self-efficacy of deaf and hard of hearing students. Paper presented at the annual meeting of the American Education Research Association, Montreal.

Lane, H. (1992). The mask of benevolence: Disabling the Deaf community. New York: Alfred A. Knopf.

Livingston, S. (1997). Rethinking the education of deaf students: Theory and practice from a teacher's perspective. Portsmouth, NH: Heinemann.

Manitoba Education and Training. (1998). Kindergarten to grade 4 English language arts: $A$ foundation for implementation. Winnipeg, MB: Manitoba Education and Training.

Mahshie, S.N. (1995). Educating deaf children bilingually: With insights and applications from Sweden and Denmark. Washington, DC: Gallaudet University Press.

Marschark, M., Lang, H., \& Albertini, J. (2002). Educating deaf students: From research to practice. New York: Oxford University Press.

McAnally, P.L., Rose, S., \& Quigley, S.P. (1999). Reading practices with deaf learners. Austin, TX: PRO-ED.

Meadow, K.P. (1972). Sociolinguistics, sign language and the Dead sub-culture. In T.J. O'Rourke (Ed.), Psycholinguistics and total communication: The state of the art (57-74). Washington, DC: American Annals of the Deaf.

Moores, D. (1987). Educating the deaf: Psychology, principles, and practices (3rd ed.). Boston, MA: Houghton Mifflin.

Neuroth-Gimbrone, C., \& Lagodice, C. (1992). A cooperative bilingual language program for deaf adolescents. Sign Language Studies, 74, 79-91.

Padden, C., \& Ramsey, C. (2000). ASL and reading ability in deaf children. In C. Chamberlain, J. Morford, \& R. Mayberry (Eds.), Language acquisition by eye (pp. 165-189). Mahwah, NJ: Erlbaum.

Peterson, S. (1995). Becoming better writers: Intended for use in language arts classrooms, grades 2-9. Edmonton, AB: FP Hendriks.

Quigley, S., \& King, C. (1981). Reading milestones. Beaverton, OR: Dormac.

Rhodes, L., \& Dudley-Marling, C. (1988). Readers and writers with a difference: A holistic approach to teaching learning disabled and remedial students. Portsmouth, NH: Heinemann.

Scardamalia, M., \& Bereiter, C. (1994). Computer support for knowledge-building communities. Journal of the Learning Sciences, 3(3), 265-281.

Schein, J.D. (1996). The demography of deafness. In P. Higgins \& J. Nash (Eds.), Understanding deafness socially (2nd ed., pp. 3-27). Springfield, IL: Charles C. Thomas.

Schleper, D. (1992). When " $\mathrm{f}$ " spells "cat": Spelling in a whole language program. Perspectives in Education and Deafness 11(1), 11-14.

Singleton, J.L., Morgan, D., DiGello, E., Wiles, J., \& Rivers, R. (2004). Vocabulary use by low, moderate, and high ASL-proficient writers compared to hearing ESL and monolingual speakers. Journal of Deaf Studies and Deaf Education 9(1), 86-103.

Stires, S. (1991). With promise: Redefining reading and writing for "special" students. Portsmouth, NH: Heinemann.

Strong, M. (Ed.). (1988). Language, learning, and deafness. Cambridge, MA: Cambridge University Press.

TESL CANADA JOURNAL/REVUE TESL DU CANADA

VOL. 25, NO 1, WINTER 2007 
Svartholm, K. (2000, July). Sign bilingual education in Sweden. Paper presented at the 19th international congress on Education and the Deaf, Sydney, Australia.

Trybus, R., \& Jensema, C. (1978). Communication patterns and education achievement of hearing impaired students. Series T, No. 2. Washington, DC: Office of Demographic Studies Gallaudet College.

Wells, G. (1986). The meaning makers: Children learning language and using language to learn. Portsmouth, NH: Heinemann.

Wilcox, S. (1994). Struggling for a voice: An interactionist view of language and literacy in Deaf education. In V. John-Steiner, C.P. Panofsky, \& L.W. Smith (Eds.), Sociocultural approaches to language and literacy: An interactionist perspective (pp. 109-138). Cambridge, UK: Cambridge University Press.

Yurkowski, P., \& Ewoldt, C. (1986). A case for the semantic processing of the deaf reader. American Annals of the Deaf, July, 243-247. 